\title{
Correction to: Silicon soil amendment as a complement to manage tan spot and fusarium head blight in wheat
}

\author{
Paulo Cesar Pazdiora ${ }^{1}$ - Keilor da Rosa Dorneles ${ }^{1} \cdot$ Thomas Natalli Morello $^{1}$ - Paul Nicholson ${ }^{2}$. \\ Leandro José Dallagnol ${ }^{1}$ (D)
}

Accepted: 16 April 2021 / Published online: 5 May 2021

(C) INRAE and Springer-Verlag France SAS, part of Springer Nature 2021

\section{Correction to: Agronomy for Sustainable Development https://doi.org/10.1007/s13593-021-00677-0}

During the publication process of abovementioned article, an error occurred in the presentation of Fig. 2. The correct Fig. 2 has been published below.
The original article has been corrected.

Publisher's note Springer Nature remains neutral with regard to jurisdictional claims in published maps and institutional affiliations.
Fig. 2 Rate applied of extra-fine limestone $(-\mathrm{Si})$ or calcium silicate $(+\mathrm{Si})$, concentration of silicon $(\mathrm{Si})$ and calcium $(\mathrm{Ca})$ available in the soil at sowing and leaf $(\mathrm{L}-\mathrm{Si})$ and spike ( $\mathrm{S}-\mathrm{Si}$ ) silicon concentration for each crop season. *Means for silicon concentration in the leaves or spikes, for each season, followed by different letters are statistically significant different by Tukey test at $P \leq 0.05$

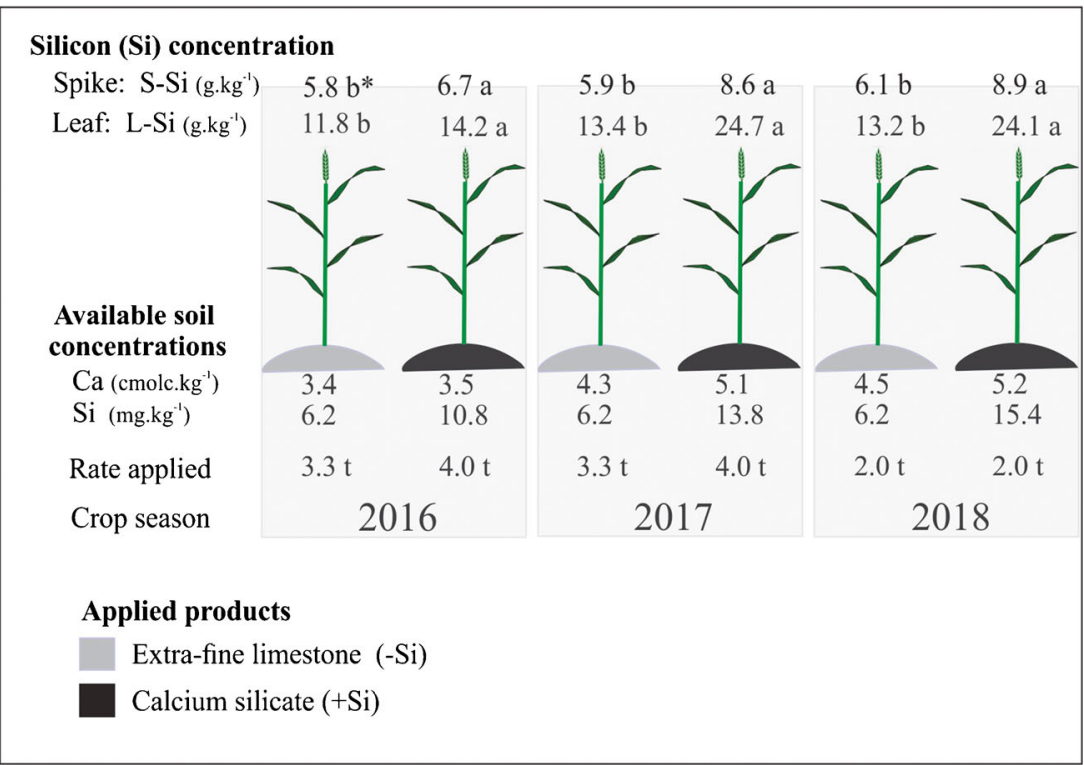

The online version of the original article can be found at https://doi.org/ 10.1007/s13593-021-00677-0

Leandro José Dallagnol

leandro.dallagnol@ufpel.edu.br

1 Eliseu Maciel Faculty of Agronomy, Crop Protection Department,

Laboratory of Plant Pathogen Interaction, Federal University of

Pelotas, Pelotas, Rio Grande do Sul 96010-900, Brazil

2 John Innes Centre, Norwich Research Park, Norwich NR4 7UH, UK 